\title{
Wpływ pandemii na polską, bułgarską i czeską leksykologię w roku 2020 i na początku 2021
}

\section{Streszczenie}

Przedmiotem uwagi są szybko następujące podczas pandemii konsekwencje językowe - leksykalne (nowe słowa, zwielokrotniona częstotliwość użycia istniejących słów) i komunikacyjne, stanowiące dla językoznawców ciekawą podstawę do badań współczesnych języków, z których trzy: polski, bułgarski, czeski stały się fundamentem analizy i badań frekwencyjnych. Mimo że omawiane procesy językowe mają charakter globalny, to tendencje leksykalne w poszczególnych językach, jak i funkcje mowy realizowane są w różny sposób, $\mathrm{z}$ heterogenicznym natężeniem, dlatego warto przyjrzeć im się bliżej.

Prezentowany w artykule materiał został wyekscerpowany z dostępnych w sieci i na bieżąco notujących jednostki języka źródeł. Były nimi korpusy językowe: Narodowy korpus języka polskiego, Bułgarski narodowy korpus, Czeski narodowy korpus, autorski Polsko-bułgarsko-rosyjski korpus równoległy, którego autorka artykułu jest współautorką, i przeglądarki typu: frazeo.pl czy slowanaczasie.pl oraz słowniki elektroniczne, na przykład miejski.pl. Pomocne stały się polskie, bułgarskie i czeskie programy publicystyczne i informacyjne, a także najmłodsza, choć nieliczna, literatura naukowa.

Słowa kluczowe: pandemia, leksykologia, słowo roku, neologizmy, teorie spiskowe, częstotliwość użycia, rok 2020, język polski, język bułgarski, język czeski

\section{Wprowadzenie}

W grudniu 2019 roku doszło do pierwszych zachorowań wywołanych nieznanym dotąd typem wirusa - nowym w populacji ludzkiej koronawirusem, który wkrótce został nazwany SARS-CoV-2. Początkowo zakażeniem objęta była prowincja Hubei w Chinach, 
jednak szybko choroba rozprzestrzeniła się po całym świecie. Światowa Organizacja Zdrowia ogłosiła stan pandemii. Temat pandemii oraz jej rezultatów stał się istotny dla sfery medycznej, gospodarczej, społecznej, ale na niej się nie zakończył.

Przedmiotem uwagi w tym artykule są szybko następujące konsekwencje językowe leksykalne (nowe słowa, zwielokrotniona częstotliwość użycia istniejących słów) i komunikacyjne, stanowiące dla językoznawców ciekawą podstawę badań współczesnych języków słowiańskich, z których trzy: polski, bułgarski i czeski stały się przedmiotem analizy.

Szczególnie szybko zachodzące podczas pandemii procesy językowe mają charakter globalny, choć ich natężenie, funkcje: komunikatywna, informatywna, ekspresywna czy impresywna widoczne są z różnym natężeniem, dlatego warte są uważniejszego przyjrzenia w bliskich sobie, bo słowiańskich, językach.

Ciekawe, że sama nazwa wirusa, który zmienił tak znacząco rok 2020, stanowi problem językowy. Wojciech Włoskowicz (2020: 98-99) za pracą Detection of 2019 novel coronavirus (2019-nCoV) by real-time RT-PCR referuje, że wirus został początkowo nazwany 2019-nCoV (Corman i in., 2020), co stanowiło skrót od roku, w którym odnotowano pierwszy przypadek zachorowania (2019) oraz od angielskiego wyrażenia: novel coronavirus, co oznacza 'nowy koronawirus'(Corman i in., 2020). W dalszej kolejności, pisze Wojciech Włoskowicz, zyskał nową nazwę: SARS-CoV-2 (van Doremalen i in., 2020), co stanowi skrót od Severe Acute Respiratory Syndrom Coronavirus 2 - drugi koronawirus wywołujący ostrą chorobę zakaźną układu oddechowego. Schorzenie wywoływane przez nowego koronawirusa nazywane jest zaś COVID-19 (Lai i in., 2020), czyli Coronavirus Disease 2019 - choroba koronawirusowa, której pierwsze rozpoznanie miało miejsce w 2019 roku.

Podstawą leksemów powstałych w odniesieniu do samego wirusa jest zatem człon corona (pol. korona, bułg. корона, cz. korona) lub niepełna nazwa choroby covid (pol. covid, bułg. ковид, cz. covid). Corona jest problematyczna w języku polskim, ponieważ niektórzy użytkownicy języka stosują człon korona zamiennie z formantem korono, co pokazano w dalszej części niniejszego tekstu.

W kwestii popularności słów z podstawą covid analiza informacji (korpusowych, prasowych, społecznościowych, naukowych) publikowanych w internecie w trzech zestawianych tu językach pokazuje, że w języku bułgarskim i języku czeskim człon covid jako część składowa nowego słowa występuje częściej niż w języku polskim. Przykłady polskie stanowią nieliczne wyniki odnajdywane dzięki internetowym wyszukiwarkom internetowym i korpusowym (tutaj zamiast rzeczownika częściej występują przymiotnikowe określenia, na przykład covidowe palce - jako opis pierwszych symptomów choroby).

Interesujący dla badań materiał stanowią wszystkie słowa odwołujące się do nowego (pandemicznego) stanu rzeczy, tj. pracy w domu, zagrożenia chorobą czy ograniczonych relacji międzyludzkich. Wzmożoną częstotliwość wykazał na przykład pochodzący z języka angielskiego leksem lockdown (pol. lockdown, bułg. локдоун, cz. lockdown,), który wielokrotnie zastępował w języku polskim, bułgarskim i czeskim rodzime słowa: pol. zamknięcie lub zakaz wyjścia, zakaz ориszczania doти, bułg. затваряне/забрана 
за излизане; cz. zákaz vycházení, zákaz opuštění domova, choć przed rokiem 2020 był w tych językach właściwie nieużywany.

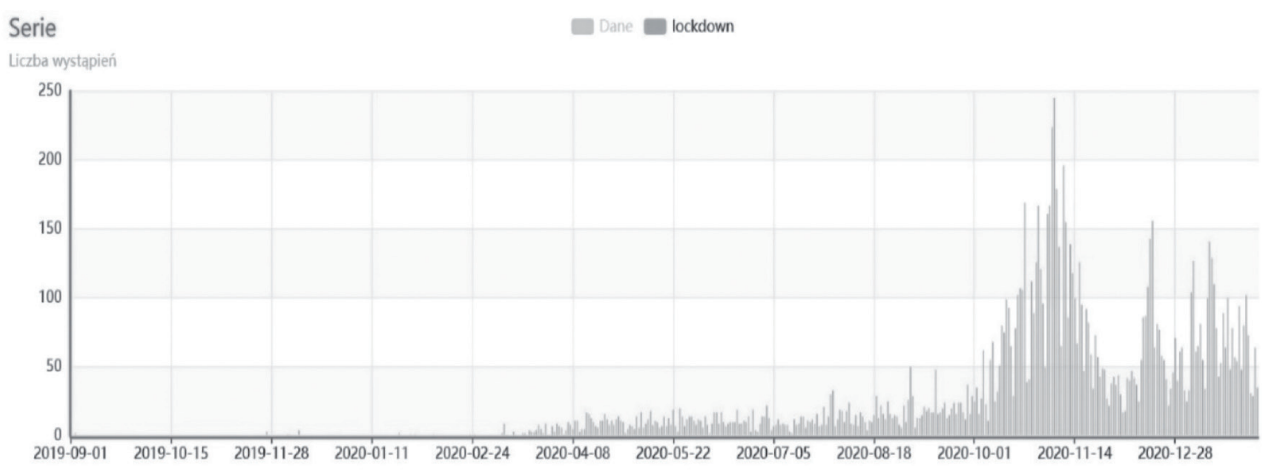

Rysunek 1. Częstotliwość użycia leksemu lockdown Źródło: Frazeo.

\section{Materiał językowy}

Prezentowany w artykule materiał został wyekscerpowany z dostępnych w sieci i na bieżąco notujących jednostki języka źródeł. Były nimi korpusy językowe: Bułgarski narodowy korpus (http://search.dcl.bas.bg/), Czeski narodowy korpus (https://korpus.cz/), Narodowy korpus języka polskiego (http://nkjp.pl/) i krajowe przeglądarki typu frazeo. pl czy slowanaczasie (http://www.slowanaczasie.uw.edu.pl/) oraz słowniki elektroniczne typu miejski.pl ${ }^{1}$. Pomocne stały się polskie, bułgarskie i czeskie programy publicystyczne $\mathrm{i}$ informacyjne.

Sięgnęłam ponadto do elektronicznej prasy, forów, blogów, portali społecznościowych, które starały się na bieżąco notować słowa i opisywać rzeczywistość. Podstawę stanowiła także „młoda” literatura naukowa na ten temat. Wywiedziony z korpusów materiał językowy stanowi duże, zróżnicowane i reprezentatywne źródło informacji o badanych jednostkach, został także sprawdzony pod względem frekwencyjności. Konfrontatywny charakter badania miał na celu odkrycie i opisanie podobieństw i różnic w zakresie ich używania. Obserwacji dokonywałam przez 10 miesięcy 2020 roku i pierwszy miesiąc roku 2021.

\section{Konfrontacja}

Pierwsze obserwacje potwierdziły hipotezę, że najliczniej występujące słowa powiązane z pandemią stanowią: (1) neologizmy, na przykład: sama nazwa choroby wywoływanej przez wirus COVID-19 czy nowe obszary bieżącej działalności człowieka albo nowe

\footnotetext{
${ }^{1}$ Niezbyt liczne, bo notowanie bieżących zmian językowych wymaga od autorów determinacji i konsekwencji; por. Słownik slangu Miejski.pl.
} 
grupy społeczne: pol. kowidowcy, bułg. ковидовичи, cz. covidovci. Wśród nowych słów odnotowano emocjonalne, często ironiczne lub złośliwe przykłady opisujące zachowania społeczne, postawy ludzkie, na przykład ignorowanie obostrzeń w pandemii: pol. COVID-idiota ,, Szury”, , foliarze”, , COVID-idioci”. Jak dyskutować z wyznawcami spiskowych teorii?, 2020) lub koronaidiota (Chaciński, 2020), bułg. ковидиот, cz. covidiot lub koronaidiot (Думата на 2020: коронавирус, 2020).

Wśród „pandemicznych” efektów leksykalnych spostrzec można także (2) słowa od dawna istniejące w omawianych językach, których, jak podają liczne źródła, częstotliwość użycia w roku 2020 znacząco wzrosła w trakcie pandemii. Odnoszą się one do elementów garderoby (odwołują się do obowiązku noszenia maseczek), utrzymywania dystansu społecznego, pozostawania w domach czy dotyczą przedmiotów ratujących życie: pol. maseczka, bułg. маска, cz. rоиška; pol. tlen, bułg. кислород, cz. kyslik; pol. dystans społeczny, bułg. сочиална дистанщия, cz. sociální vzdálenost; pol. kwarantanna, bułg. карантината, cz. karanténa; pol. maska tlenowa, bułg. кислородна маска, cz. kyslíková maska; pol. respirator, bułg. pecnupamop, cz. respirátor; pol. pandemia, bułg. пандемия, cz. pandemický.

Są wśród obserwowanych jednostek języka także (3) kalki językowe - nowe w języku polskim, bułgarskim i czeskim słowa pochodzące z języka angielskiego, z których najpopularniejszym jest ang. lockdown - pol. lockdown, bułg. локдаун, cz. lockdown .

Popularność zdobyły również (4) wyrażenia odnoszące się do sytuacji politycznych i społecznych: pol. głosowanie korespondencyjne, bułg. гласуване по пощата (Думата на 2020: коронавирус, 2020), cz. korespondenčni hlasování, a także nasilających się postaw społecznych, w tym teorii spiskowych: pol. teorie spiskowe lub QAnon (medialna, zbiorcza nazwa teorii spiskowych), którego częstotliwość użycia wzrosła o 960\% (Коя е Думата на Безпрецедентната 2020 Г.?, 2020), bułg. конспиративни теории, cz. konspiračni teorie.

Powszechność teorii spiskowych oraz błędnych informacji związanych z nowym koronawirusem jest tak znaczna, że od lutego 2020 roku Światowa Organizacja Zdrowia posługuje się symbolicznym terminem, określającym obecny stan rzeczy. Brzmi on: infodemia (infodemic) i stanowi połączenie słów informacja oraz pandemia (information, pandemic). Można by sądzić, pisze o tym doktorantka Marta Trzeciak, że teorie spiskowe czy nieprawdziwe informacje na temat koronawirusa należy traktować raczej z pobłażliwością, z bieżących obserwacji wynika, iż dezinformacja oraz teorie spiskowe dotyczące COVID-19 mogą stanowić realne zagrożenie dla ludności. Wynika to nie tylko z przyczyn typowo medycznych, ale też z tych społecznych. Aby objaśnić możliwe zagrożenia tego typu badaczka Marta Trzeciak w pracy dyplomowej pt. Dziennikarstwo naukowe - rzetelność , w czasach zarazy” omawia jeden kontekst, w ramach którego teorie spiskowe mogą okazać się bardzo groźne. Jest nim powiązanie strachu przed infekcją z przynależnością etniczną lub rasową (Trzeciak, 2020: 51).

Wśród językoznawców (Casper Grathwohl, Vladislav Milanov, Michaela Lišková, Marek Łaziński, Henryk Duda, Maciej Malinowski, Joanna Satoła-Staśkowiak, Wojciech Włoskowicz) najczęściej pojawia się opinia, że wszystkie języki podlegają rozwojowi, ale wpływ obecnej sytuacji epidemiologicznej sprawia, że dzieje się to o wiele szybciej 
niż kiedykolwiek w historii języków. Potwierdzają to dostępne w sieci źródła. Częściowo wynika to z mediów i ich wpływu na sieci społecznościowe: Facebook, Instagram, Twitter i innych, w których słowa lub wyrażenia, takie jak bułgarskie wkysztestwuwam (bułg. вкъществувам 'żyję/funkcjonuję na terytorium własnego domu’) lub żartobliwe pyk tazi dyłga duma, kojato ne se naemam da proczeta (bułg. пък тази дълга дума, която не се наемам да прочета - 'to długie słowo, którego nie podejmuję się przeczytać') w odniesieniu do wyrażenia neprotiwokoronawiruso-karantinoizołacion-snowatetstwuwajte (bułg. непротивокоронавирусо-карантиноизолацион-снователствувайте ${ }^{2}$ ), stają się natychmiast popularne, chętnie modyfikowane, na przykład skracane przez mówiących (Новите думи в българския език, 2020).

Autorzy tak zwanego Słownika Oksfordzkiego ${ }^{3}$ sporządzili listę słów charakterystycznych dla 2020 roku. Lista ta zawiera nie tylko leksemy, ale także wyrażenia które są swoiste dla tego wyjątkowego czasu. Są wśród nich na przykład: Covid-19, lockdown, praca $w$ domu, spiskowe teorie, głosowanie korespondencyjne i inne jeszcze słowa nawiązujące do czasu epidemii lub ją nazywające. Prezes Stownika Oksfordzkiego Casper Grathwohl zauważa, że użycie leksemu pandemia w roku 2020 wzrosło o 57 000\% w porównaniu z rokiem wcześniejszym ${ }^{4}$. Słowo to stało się popularne globalnie.

\section{Języki słowiańskie w pandemii}

\section{Język polski - wybrane przykłady}

W roku 2020 językoznawcy w Polsce dość szybko zaczęli dokumentować częstotliwość występowania nowych „koronawirusowych” słów, analizować ich budowę i znaczenie, a także opatrywać je komentarzami w audycjach radiowych (Włoskowicz ${ }^{6}$ ), artykułach prasowych (Satoła-Staśkowiak, 2020), publicznych postach (Łaziński) i blogach (Malinowski ${ }^{7}$, Duda $^{8}$ ), wystąpieniach telewizyjnych (Laziński ${ }^{9}$; Satoła-Staśkowiak ${ }^{10}$ ), uznając, że sytuacja warta jest uwagi. Obserwację nowych lub na nowo używanych i popularnych słów prowadzą także naukowcy na Uniwersytecie Warszawskim. Ich uwagę zyskują pochodzące z mediów, dzienników słowa, z których najpopularniejsze mają szanse stać się słowem roku.

\footnotetext{
2 Zestawienie kilku słów: kwarantanna, izolacja, koronawirus, przeciwwirusowy.

3 Zespół z Oksfordu każdego roku monitoruje zmiany w języku angielskim i ogłasza słowo, które dany rok charakteryzuje. Zidentyfikował setki znaczących, nowych słów i ich zastosowanie w ciągu 2020 roku, z których kilkanaście nie kwalifikowałoby się jako „słowo roku” w żadnym innym czasie. „Jest to bezprecedensowe i trochę ironiczne - rok, w którym zaniemówiliśmy, obfitował w nowe słowa bardziej niż jakikolwiek inny", por. Дyмama на 2020: коронавирус, 2020.

4 Por. „Площад Славейков“, Думата на 2020: коронавирус, 2020.

5 Opracowanie na podstawie Chaciński, 2020.

618 marca 2020 roku w radiowym felietonie w Programie Czwartym Polskiego Radia.

724 marca 2020 roku.

829 kwietnia 2020 roku.

96 stycznia 2021 roku - stacja TVN.

1015 czerwca 2020 roku - Telewizja Aleksandrów Łódzki.
} 
Wspomniane we wstępie problemy związane w języku polskim z obocznością koronawirus do koronowirus opisał W. Włoskowicz (2020: 88-111), podkreślając reinterpretację angielskiego terminu coronavirus na płaszczyźnie języka polskiego. Otóż naukowy $\mathrm{i}$ angielskojęzyczny termin coronavirus stał się podstawą zapożyczenia dokonanego do polskiej terminologii naukowej. Jako polski termin koronawirus pozostawał zasadniczo poza leksyką języka ogólnego. W polskim języku specjalistycznym często pojawiał się też w liczbie mnogiej jako nazwa grupy wirusów (Włoskowicz, 2020).

Forma terminu naukowego koronawirus po zapożyczeniu do polskiego zasobu terminologicznego uzyskała postać zbliżoną do polskiego zrostu. Oczywiście właściwy proces słowotwórczy odbył się na gruncie angielszczyzny $-\mathrm{z}$ członów łac. corona + ang. virus powstało typowe compositum (compound noun) w typie ortograficznym z pisownią łączną - w związku z czym z perspektywy polskiego opisu słowotwórczego otwiera się pole do rozważań nad tym, czy koronawirus można w polszczyźnie uznać za złożenie lub wyraz podzielny słowotwórczo (Włoskowicz, 2020: 98-111; Pyrć, 2015: 48-54).

Krótko mówiąc, polski termin koronawirus przypomina polski zrost, a działalność słowotwórcza zrostu ma znacznie mniejszą produktywność niż mechanizm złożenia. Ponieważ forma koronawirus jest wtórną pożyczką zapożyczenia korona-wirus, wpisuje się na długą listę polskich złożeń typu: gwiazdozbiór, roślinożerca, deskorolka (przykłady za Włoskowicz, 2020: 103). Zamiana polskiego terminu naukowego koronawirus do postaci koronowirus ma związek z wyborem popularniejszego modelu słowotwórczego, jakiemu ulegają niektórzy użytkownicy współczesnej polszczyzny. Jak podaje prowadzona przez naukowców z Uniwersytetu Warszawskiego strona Słowa na czasie, w okresie obejmującym miesiące od marca do czerwca słowa koronawirus używamy częściej niż zwykle.

Frekwencyjna historia użycia słowa koronawirus w Polsce przedstawia się bardzo ciekawie i działa na wyobraźnię, szczególnie kiedy jako początek badania ustali się okres wcześniejszy niż rok 2020 (na przykład jak na wykresie czas od 1 października 2019 roku do 31 grudnia 2020 roku).

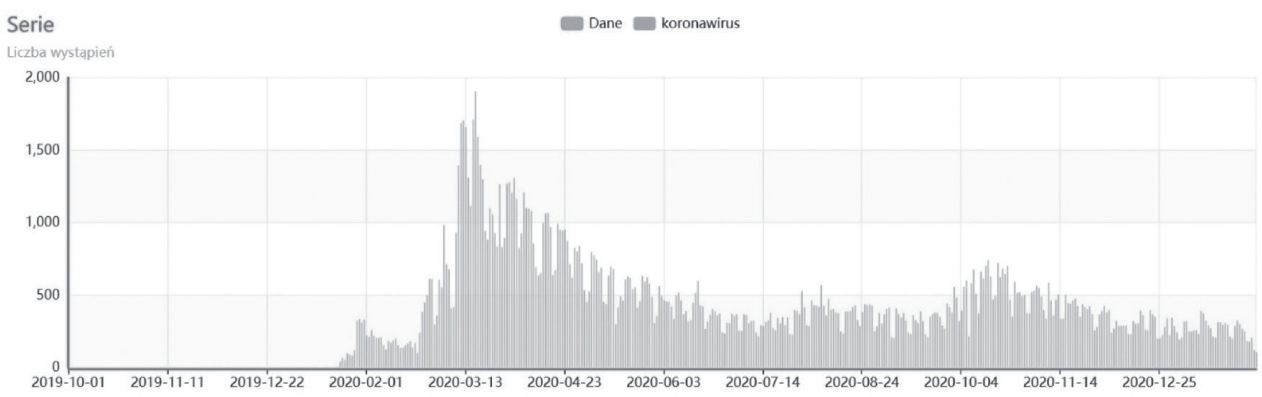

Rysunek 2. Częstotliwość użycia słowa koronawirus w Polsce

Źródło: Frazeo.

Do częściej używanych w minionym roku w polskich tekstach informacyjnych należą głównie rzeczowniki, nazwy własne i skróty (wybrane przykłady): epidemia, pandemia, zdrowie, zakażenie, kwarantanna, test, personel, doba, tarcza, obostrzenie, ograniczenie, 
wzrost, walka, specustawa, szpital, przyłbica, maseczka, respirator, dom, głosowanie, izolatorium, wideoporada, usta, nakaz, ozdrowieniec, zgon, COVID-19, koronawirus; przymiotniki (wybrane przykłady): antykryzysowy, zakażony, korespondencyjny, ochronny, jednoimienny; czasowniki: odmrozić/odmrażać, zakazić, wyzdrowieć, wykryć, odnotować, umrzeć, ograniczać, odnotować, otworzyćlotwierać. Wśród neologizmów powstałych z członem korona- znajdują się posiadające element ironii rzeczowniki: koronaparty, koronalia, koronagedon, koronazakupy (Satoła-Staśkowiak, 2020: 10).

Językoznawca M. Łaziński wymienia w publicznym poście ponad 40 poświadczonych tekstowo neologizmów z członem korona- odnalezionych w wyszukiwarce frazeo.pl. Są nimi na przykład nazwy będące odniesieniem do polskiej i globalnej sytuacji gospodarczej i politycznej: koronaceny, koronademokracja, koronakryzys, koronaobligacje; do sytuacji psychicznej obywateli: koronadepresja, koronapanika, koronaterror; do sytuacji organizacji służby zdrowia: koronainfolinia, koronachaos, koronatest; do organizacji nauki koronamatura; do ignorancji stanu rzeczy przez obywateli: koronaferie, koronagtuptas, koronalans, koronalia, a nawet koronaświrus (Słownik slangu Miejski.pl) jako łagodniejszy odpowiednik COVID-idioty. Im bliżej końca 2020 roku, tych słów wymienić można znacznie więcej. Istotne, że za popularną podstawę zupełnie nowych polskich słów należy uznać formant korona, który jest nieproporcjonalnie bardziej popularny od formantu covid.

5 stycznia 2021 roku w Polsce kapituła Konkursu „Słowo Roku” organizowanego przez Instytut Języka Polskiego Uniwersytetu Warszawskiego i Fundację Języka Polskiego wyłoniła słowo roku 2020. Słowa wybrano spośród listy słów zaproponowanych przez organizatorów lub przesłanych jako własne propozycje za pomocą formularza na stronie sloworoku.uw.edu.pl. W plebiscycie internetowym oddano blisko 18 tys. głosów. Na pierwszym miejscu pod względem popularności w plebiscycie uplasowało się słowo koronawirus, następnie słowa: kobiety, apostazja. Za to składająca się ze specjalistów kapituła zagłosowała na następujące słowa: koronawirus, kobiety, pandemia. Wybrane słowa oddają historię 2020 roku, która w Polsce upłynęła w atmosferze walki z pandemią i strajków kobiet.

\section{Język bułgarski - wybrane przykłady}

W połowie 2020 roku bułgarscy eksperci podkreślają, że słowo коронавирус (koronawirus) z pewnością dobrze opisuje cały 2020 rok, ale nie stanie się bułgarskim słowem roku, bo samo słowo funkcjonuje w języku mniej więcej od lat sześćdziesiątych minionego wieku (por. Думата на 2020: коронавирус, 2020). Vladislav Milanov twierdzi:

Всяка промяна в обществото води до промени в езика. Езикът намира начин, по който да реагира [...] Езикът си има свои правила. Само че от време на време се намесваме в тях и се получава това: „карантинирам”, „коронясване по-скоро”, „вкъществувам”, „вкъществуване примерно”, „карантинирам определено”, „карантиниране на пътникопотока след термометриране” и „тестуване”. И това не е само при нас - езикът, според езиковедите, няма право да ни се сърди. (Każda zmiana w społeczeństwie prowadzi do zmian w języku. Język znajduje sposób na reakcję [...] rządzi się swoimi prawami. Jednak od czasu do czasu zdarza się tak, że pojawiają się w nim [języku] takie [liczne modyfikacje] jak: „карантинирам”, „коро- 
нясване по-скоро”, „вкъществувам”, „вкъществуване примерно”, „карантинирам определено”, „карантиниране на пътникопотока след термометриране” и „тестуване". Tak dzieje się nie tylko u nas - dlatego, zdaniem lingwistów, język nie ma prawa się na nas [jego użytkowników - przyp. autorki] gniewać) $)^{11}$.

Casper Grathwohl powiedział:

Nigdy nie byłem świadkiem takiego, jak ten, roku językowego. [...] To jest zarówno bezprecedensowe, jak i nieco ironiczne, że rok, w którym zaniemówiliśmy [przestaliśmy rozmawiać z innymi, byliśmy osamotnieni - przyp. autorki], był pełen nowych słów bardziej twórczy niż jakikolwiek inny ${ }^{12}$.

Niektóre używane w języku bułgarskim słowa będą z powodu 2020 roku używane znacznie ostrożniej, stanie się tak na przykład z koronjasan - bułg. коронясан ('koronowany'). Za to, jak podkreśla Vladislav Milanov, nowe słowo karantiniram (bułg. карантинирам) pozostanie w języku bułgarskim na dłużej, szczególnie że może zastąpić zbyt długie dla żyjących w pośpiechu ludzi wyrażenie: postawjam pod karantina (bułg. поставям под карантина - 'przebywać w kwarantannie'). Nowe w bułgarskim słowniku wynikające z pandemii słowa to: srutiszte (bułg. cpymume - 'upadek, runięcie'), wakancuwam (bułg. ваканцувам - 'przymusowe wakacje/zwolnienie z pracy'), wchodiram (bułg. входирам); agresiram (bułg. azpecupan - 'stawać się agresywnym pod wpływem sytuacji'), prioritiziram (bułg. приоритизирам - 'ustanawiać nowe priorytety') (Думата на 2020: коронавирус, 2020).

W bułgarskich mediach nowe słowa z członem корона są codziennością. Mamy więc: korona + sztab, linija, isterija, żertwi, epidemija, wirus, wirusen, bjudżet, situacija, bonowe, krizisen; bułg. корона + щаб, линия, истерия, жертви, епидемия, вирус, вирусен, бюджет, ситуация, бонове, кризисен - koronasztab (bułg. коронащаб); koronalinija (bułg. короналиния); koronaisterija (bułg. коронаистерия); kоronażertwi (bułg. коронажертви); koronaерidemija (bułg. коронаепидемия); kоronawirus (bułg. коронавирус); koronawirusen (bułg. коронавирусен), kоronabjudżet (bułg. коронабюджет); koronasituacija (bułg. коронаситуация); koronabonowe (bułg. коронабонове); koronakrizisen (bułg. коронакризисен).

Wśród ostatnio silnie produktywnych sufiksów klasyfikuje się -iram (bułg. -upam), mamy na przykład: karantiniram (bułg. карантинирам - 'podlegać kwarantannie'), mоnitoriram (bułg. мониторирам - 'monitorować'), prioritiziram (bułg. приоритизирам 'ustanawiać priorytety') itd.

Ironiczne okazjonalizmy, które z racji popularności zaliczymy do neologizmów o coraz szerszym zasięgu, to: kowidiot, koronaparti (bułg. ковидиот, коронапарти; zob. Атанасова, 2020), na przykład Policija szturmuwa chotet zaradi skandatno koronaparti

11 Przykładem omawianych modyfikacji jest między innymi wspomniany wyżej „niedookreślony” zdaniem Milanova i znacznie popularniejszy w ostatnich miesiącach termin тестувам, w miejsce istniejącego тествам. Oba związane z testowaniem pacjentów na koronawirusa, zob. Йорданова, 2020.

12 Słowa, którym badacze z Oxfordu przyjrzeli się w 2020 roku, są podzielone na kilka głównych kategorii: ,język Covid-19”, „technologia i praca z domu”, „ruchy społeczne, media społecznościowe i polityka” oraz ,środowisko", por. Думата на 2020: коронавирус, 2020. 
(bułg. Полищия щурмува хотел заради скандално коронапарти - 'Policja szturmuje hotel z powodu skandalicznego koronaparty').

Wśród nowych, powstałych w roku 2020, słów mamy maskne (bułg. маскне - połączenie słów maska i trądzik, które mają odnosić się do częstego noszenia maski na twarzy i pojawienia się w związku z tym wyprysków na policzkach i brodzie). Z członem kovid (bułg. ковид) popularność zdobył neologizm kovidbałon (bułg. ковидбалон - 'ludzie, z którymi kontaktujemy się, ryzykując zarażenie swoje lub ich, którzy nie są naszą rodziną'). Podobne znaczenie ma nowy termin karantim (bułg. карантим odnoszące się do dwóch słów karantina, bułg. карантина - 'kwarantanna' + tim, bułg. muм - 'zespół', tj. 'osoby spędzające z nami czas kwarantanny').

Odniesienie do złego samopoczucia psychicznego odnajdujemy w języku bułgarskim w popularnym neologizmie dumskroling (bułg. думскролинг - 'nieustajca potrzeba przeszukiwania internetu w celu znalezienie złych informacji', od ang. Doom - 'poczucie nieuchronności losu, zagłady' i ang. scrolling - 'przewijanie, przeszukiwanie internetu').

Fraza bezkontaktna dostawka (bułg. безконтактна доставка - 'dostawa bezkontaktowa') to również całkiem nowa fraza, która w ostatnich miesiącach zyskała ogromną popularność. Dotyczy na przykład takich sytuacji, w których kurier dowozi nam pod drzwi zamówienie opłacone przelewem.

Interesującym nowym terminem jest także kowekzit (bułg. ковекзиm), które opisuje strategię i działanie osób chcących uniknąć lockdownu.

21 listopada 2020 roku w gazecie „Buleward Bylgarija” (bułg. „Булевард България”) na pytanie dziennikarza, jakie jest bezprecedensowe słowo roku w Bułgarii, czytamy, że twórcy rankingu „Słowo Roku” zdecydowali, że zamiast zajmować się jednym słowem warto wskazać zestaw słów, których używanie na zawsze będzie kojarzone z upływającym rokiem. Cechą wspólną wymienionych przez ekspertów słów miał być nastrój całego minionego 2020 roku. Z pewnością ów nastrój podkreśla bijąca wszelkie rekordy popularności (poza samym koronawirusem), pochodząca z języka angielskiego kalka językowa lockdown (pol. lockdown, bułg. локдаун, cz. lockdown,) (Коя е Думата на Безпрецедентната 2020 Г.?, 2020).

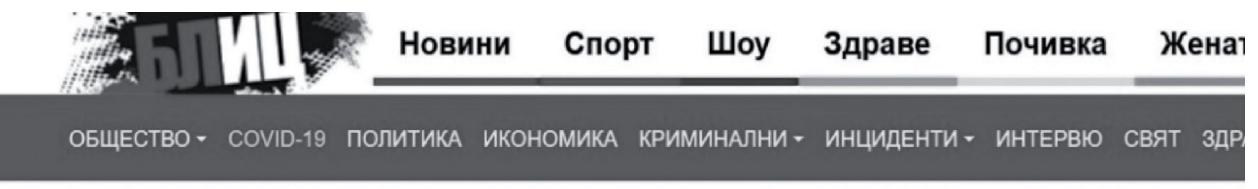

\title{
Испанското правителство изключва нов локдаун
}

\begin{abstract}
Не планираме в момента никакво затваряне по домовете, съобщи министърът на здравеопазването
\end{abstract}

Rysunek 3. Przykładowy bułgarski tytuł prasowy zawierający informację o lockdownie Źródło: https://blitz.bg/. 
Nawiązując do wspomnianego już języka angielskiego, chętnie adaptowanego przez młodych użytkowników do języka bułgarskiego, warto wspomnieć, że w kontekście pracy zdalnej czy nauki na odległość frekwencja użycia terminów remote/remotely ${ }^{13}$ zwielokrotniła się w roku 2020 o 300\%. Spopularyzowało się także użycie terminów dotyczących życia w pandemii i korzystania z aplikacji wspierających kontakty na odległość, takich jak Teams, Zoom, Discord i ich narzędzi (por. terminy mute/unmute odnoszące się do włączania i wyłączania dźwięków). Na szczególną uwagę zasługują także terminy worcation i staycation. Pierwszy oznacza 'wakacje, podczas których trzeba pracować', drugi 'wakacje, które spędza się w domu lub na wsi'.

W języku bułgarskim notujemy w związku z tym nowe słowo zumping (bułg. Зумпинг; zob. Вацова, 2020), które jest semantycznie wzorowane na angielskim słowie dumping ('wyrzucać, rzucać, pozbywać się, sprzedawać informacje’). Oznacza sytuację, w której albo partner cię rzucił, albo szef zwolnił podczas rozmowy wideo za pośrednictwem aplikacji Zoom. Ten neologizm jest czytelnym i smutnym przykładem zmian nie tylko w języku, ale także w relacjach społecznych 2020 roku.

\section{Język czeski - wybrane przykłady}

W trakcie pisania tego artykułu w Czechach i Polsce wybierano właśnie słowo roku 2020. W Czechach stało się to po raz pierwszy w oficjalnym konkursie. Liczne czeskojęzyczne źródła podają, że pandemia i Covid-19 przyczyniły się do powstania ponad 100 nowych słów i wyrażeń (, Коронаидиот” "или covidiot: Чехите си измислиха повече от 100 нови думи и фрази, 2020). Część nowych słów jest odpowiednikiem tych, znanych w bułgarszczyźnie, polszczyźnie i innych współczesnych językach wymienianych już wyżej w tym artykule. Jak pisze Petr Juna na łamach gazety „Seznam Zprávy”, wybrane w pierwszym czeskim konkursie ,słowo roku” można odgadnąć w ciągu sekundy. Jest nim koronavirus.

Faktycznie, nie ma tu dużego zaskoczenia, zaskoczenia nie ma też, gdy zapoznamy się z kolejnymi słowami, bo w dalszej kolejności, w odniesieniu do ich frekwencji, wyłoniono słowa: pandemie (pol. pandemia, bułg. пандемия), karanténa (pol. kwarantanna, bułg. карантина,), nakažený( pol. zakażony, bułg. заразен) i rouška (pol. maseczka, bułg. маска).

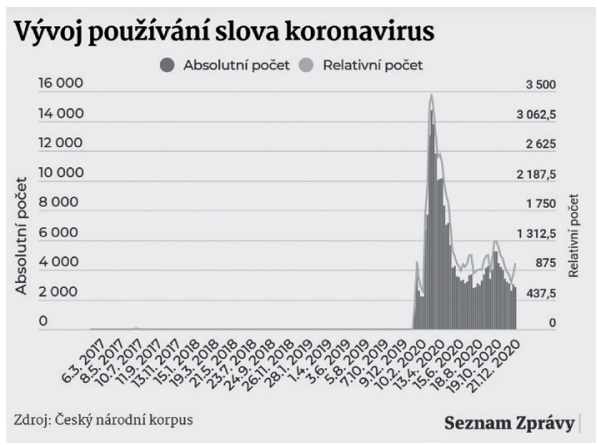

Frekwencja słowa „koronawirus”

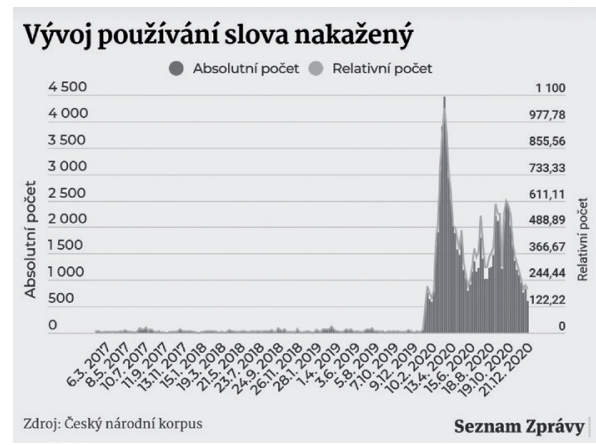

Frekwencja słowa „zakażony”

13 Jedno z jego znaczeń brzmi ‘zdalnie, na odległość’ i było używane w kontekście pracy na odległość i uczenia się. 


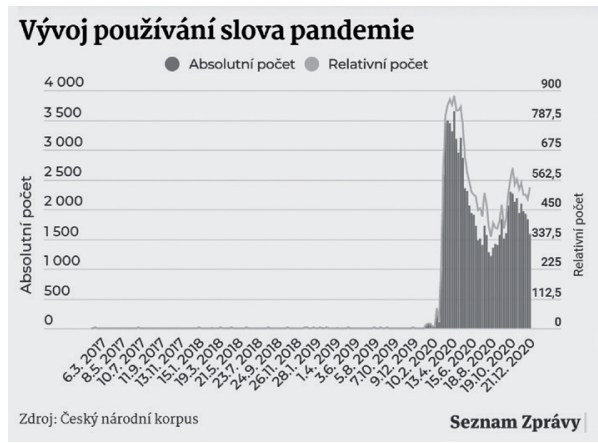

Frekwencja słowa „pandemia”

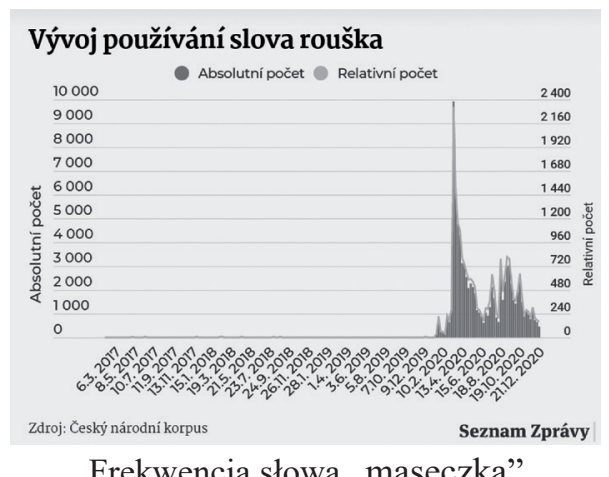

Frekwencja słowa „maseczka”

Źródło: Český národní korpus.

Václav Cvrček, zastępca dyrektora Czeskiego narodowego korpusu, wyjaśnia:

To jsou slova, jejichž výskyt v roce 2020 prudce vzrostl (oproti letům předcházejícím) a která mají potenciál nejlépe zachytit to, o čem jsme v roce 2020 nejvíc psali (a četli). [Są to słowa, których użycie gwałtownie wzrosło w 2020 roku (w porównaniu z poprzednimi latami) i mają potencjał, aby najlepiej uchwycić to, o czym najwięcej napisaliśmy (i przeczytaliśmy) w 2020 roku.] (Juna, 2020).

Michaela Lišková, specjalistka w zakresie neologizmów w Instytucie Języka Czeskiego Czeskiej Akademii Nauk, sądzi, że większość powstałych lub używanych podczas pandemii słów zniknie z języka po ustaniu epidemii. Z pewnością mogą zaliczać się tu słowa ironiczne, emocjonalne (nawet wulgaryzmy) czy okazjonalne, będące odpowiedzią na nieodpowiedzialność zachowania ludzi, śmieszność czy nielogiczność wprowadzanych obostrzeń, nierzetelność informacji itp. Taką grupę mogą stanowić leksemy, których emocjonalność jest cechą przewodnią, na przykład covidiot, koronaidiot - 'osoba w nieodpowiedzialny sposób ignorująca i zaniedbująca środki zapobiegawcze związane z Covid-19' (pol. COVID-idiota, ,Szury”, , foliarze”, ,COVID-idioci”. Jak dyskutować z wyznawcami spiskowych teorii?, 2020; bułg. коронаидиот).

W języku czeskim, tak jak w języku bułgarskim i polskim, obserwowane i notowane są także słowa i wyrażenia nawiązujące bezpośrednio do stanów psychicznych człowieka, wywołanych przedłużającą się pandemią: koronadeprese (pol. koronadepresja, bułg. коронадепресия); koronapanika (pol. koronapanika, bułg. коронапаника); koronapokalypsa (pol. koronaapokalipsa, bułg. коронаапокалипсис).

Konieczność pozostania w domu i utrzymywania dystansu społecznego stała się powodem istnienia takich czeskich neologizmów, jak: koronadovolená (pol. koronawakacje, bułg. коронаваканция); škola v руžати (pol. szkoła w piżamie, bułg. училище по пижами).

Z danych Czeskiego narodowego korpusu (ČNK), monitorującego między innymi media internetowe, dyskusje i portale społecznościowe, dowiadujemy się, które słowa były używane w roku 2020 częściej od innych i to stanowi charakterystykę tego wyjątkowego roku. 
W 2020 roku powody powstawania nowych czeskich słów, zwielokrotnienie użycia słów od dawna znanych, liczne pożyczki z języka angielskiego są oczywiste. Konsekwencją są listy nowych haseł i wyrażeń, z których część z pewnością zostanie na jakiś czas w języku. Václav Cvrček informuje, że wiele całkiem nowych słów to nazwy własne lub słowa wywodzone z języka technicznego czy specjalistycznego. Jak mówi:

V každém živém jazyce, a tedy i v češtině, probíhají změny. Mluvčí to často nesou nelibě, neuvědomují si přitom, že je to prrirozená součást jazykového vývoje a toho, jak naše komunikace reaguje na proměny světa okolo nás. [Zmiany zachodzą w każdym żywym języku, a więc także w języku czeskim. Użytkownicy często nie chcą tego zaakceptować, nie zdając sobie sprawy, że jest to naturalna część rozwoju języka, który reaguje na zmiany w otaczającym nas świecie.] (Juna, 2020).

\section{Podsumowanie}

Tematem artykułu były leksykalne konsekwencje językowe pandemii obserwowane w trzech słowiańskich językach: polskim, bułgarskim i czeskim. Przedmiotem analizy stały się neologizmy powstałe w 2020 roku, opisujące nowe rzeczy, zachowania, sytuacje, zjawiska, emocje oraz słowa znane lub zapożyczone, których częstotliwość użycia znacznie wzrosła w omawianym czasie, na przykład: zachorowalność, śmiertelność, pandemia. Materiał badań stanowiły wszelkie dostępne źródła dokumentujące wpływ pandemii na polską, bułgarską i czeską leksykografię w roku 2020 i początku 2021.

Część nowych słów tworzona była na członach corona lub covid. Badania pokazują, że najmniej licznymi nazwami z członem covid pochwalić może się język polski, w którym konsekwentnie chętniej wybierany za podstawę był człon korona. Dziś wiemy, że w językach bułgarskim i czeskim człon covid wykorzystano i nadal wykorzystuje się liczniej i bardziej twórczo niż w języku polskim.

Będące konsekwencją pandemii leksemy można śmiało zaszeregować według różnych kategorii, na przykład sposobów funkcjonowania ludzi/społeczeństw w pandemii czy nastrojów społecznych. We wszystkich językach są one tożsame, bo wynikają z globalności problemu pandemii. Język polski wyodrębnił dodatkowy problem istnienia równolegle słów koronowirus i koronawirus.

We wszystkich trzech językach licznie używano określeń regulujących pandemiczną codzienność: kwarantanna, domowa izolacja, maseczki, testowanie, a nawet haseł wybory korespondencyjne czy teorie spiskowe. To ostatnie znalazło w ostatnim czasie podatny grunt i silniej niż zwykle było werbalizowane, dlatego można postawić tezę, że być może w dalszej konsekwencji popularnymi w najbliższym czasie słowami mogą być takie słowa, jak dezinformacja ${ }^{14}$.

${ }^{14}$ Oficjalna strona „obalająca mity” dotyczące koronawirusa, stworzona przez Światową Organizację Zdrowia: Coronavirus disease (COVID-19) advice for the public: Myth busters, 2021 (https://www.who.int/emergencies/ diseases/novel-coronavirus-2019/advice-for-public/myth-busters). Na stronie tej gromadzone są najpopularniejsze dezinformacje, mity oraz teorie spiskowe dotyczące koronawirusa wraz z objaśnieniami, publikacjami naukowymi, infografikami itp. 
Szczególnie szybko zachodzące podczas pandemii procesy językowe mają charakter globalny, choć ich natężenie, funkcje mowy - komunikatywna, informatywna, ekspresywna, impresywna - pojawiają się, co oczywiste, z różnym nasileniem.

Po rocznej obserwacji trzech opisanych w artykule języków słowiańskich stoję na stanowisku, że nadal warto śledzić „,pandemiczne” rezultaty widoczne w leksykografii oraz tendencje współczesnych języków i konfrontować je ze sobą. Ta obserwacja warta jest poszerzenia o kolejne języki, bo w każdym z nich notuje się cechy tożsame, jak i indywidualne, charakterystyczne dla konkretnej grupy, społeczności i mentalności ludzkiej, które w wyjątkowym czasie pandemii dochodzą do głosu silniej niż kiedykolwiek ${ }^{15}$. Obserwacja jednostek i tendencji tak wyrazistych i szybko postępujących bywa dla językoznawców nie tylko satysfakcjonująca, ale także emocjonująca.

\section{Bibliografia}

„Szury”, „foliarze”, „COVID-idioci”. Jak dyskutować z wyznawcami spiskowych teorii? (2020), ,Kultura Liberalna”, https://kulturaliberalna.pl/2020/09/08/szury-foliarze-covid-idiocijak-dyskutowac-z-wyznawcami-spiskowych-teorii/ [dostęp: 19.11.2021].

„Коронаидиот” или covidiot: Чехите си измислиха повече от 100 нови думи и фрази (2020), https://news.bg/world/koronaidiot-ili-covidiot-chehite-si-izmisliha-poveche-ot-100novi-dumi-i-frazi.html [dostęp: 19.11.2021].

Chaciński B. (2020), Korona na języku, czyli pandemia w polszczyźnie, https://www.polityka. pl/tygodnikpolityka/ludzieistyle/1961694,1, korona-na-jezyku-czyli-pandemia-w-polszczyznie. read [dostęp: 19.11.2021].

Corman V.M., Landt O., Kaiser M., Molenkamp R., Meijer A., Chu D.K., Mulders D.G. (2020), Detection of 2019 novel coronavirus (2019-nCoV) by real-time RT-PCR, „Eurosurveillance”, Vol. 25(3).

Coronavirus disease (COVID-19) advice for the public: Mythbusters (2021), https://www. who.int/emergencies/diseases/novel-coronavirus-2019/advice-for-public/myth-busters [dostęp: 22.11.2021].

Doremalen N. van, Bushmaker T., Morris D.H., Holbrook M.G., Gamble A., Williamson B.N., Lloyd-Smith J.O. (2020), Aerosol and surface stability of SARS-CoV-2 as compared with SARS-CoV-1, „New England Journal of Medicine”, Vol. 382(16).

Duda H. (2020), Korona «koronawirus», Lingwistykon, https://lingwistykon.wordpress. com/2020/04/24/korona-koronawirus/ [dostęp: 10.10.2020].

Juna P. (2020), V Česku poprvé vybrali slovo roku. Vitěze uhádnete za vteřinu, https:// www.seznamzpravy.cz/clanek/slovo-roku-neprekvapi-je-to-koronavirus-135335? fbclid=IwAR0aNlNafHhx83QrAZnx44f6r1HmR8nrc9piTPfx7leoL90UeNbUYoT9-F0 [dostęp: 22.11.2021].

15 Jako ciekawostkę warto wspomnieć (dla porównania z trzema analizowanymi w artykule językami), że w Belgii słowem roku stało knuffelcontact (od knuffel - 'przytulas' i contact), czyli osoba spoza gospodarstwa domowego, z którą możemy mieć fizyczny kontakt podczas pandemii. Na drugim był covidioot, a na trzecim hoestschaamte, czyli strach przed zakaszleniem w miejscu publicznym (por. Nieuw woord 2021 - stuur het nu in!, 2021). 
Lai C.C., Shih T.P., Ko W.C., Tang H.J., Hsueh P.R. (2020), Severe acute respiratory syndrome coronavirus 2 (SARS-CoV-2) and corona virus disease-2019 (COVID-19): the epidemic and the challenges, „International Journal of Antimicrobial Agents”, Vol. 55(3).

Łaziński M. (2020), Marek Łaziński, Facebook, https://www.facebook.com/m.lazinski/ posts/2916970495090011 [dostęp: 3.10.2020].

Malinowski M. (2020), Koronawirus, Obcy język polski, https://obcyjezykpolski.pl/koronawirus/ [dostęp: 9.10.2020].

Nieuw woord 2021 - stuur het nu in! (2021), Woord van het Jaar, https://woordvanhetjaar. vandale.be/nl?fbclid=IwAR036ohnl9W6bCmDqZ6TbdECrd VVTzgqZAqmAhBcwUi3sk ymSrRqVeqzA [dostęp: 22.11.2021].

Pyrć K. (2015), Ludzkie koronawirusy, „Postępy Nauk Medycznych”, t. XXVIII, z. 4B. [Tam także zwięzły medyczny szkic o epidemii SARS i MERS z początku XXI w.]

Satoła-Staśkowiak J. (2020), Słowa w pandemii, „40 i Cztery”, nr 12(610).

Trzeciak M. (2020), Dziennikarstwo naukowe - rzetelność ,,w czasach zarazy”, Praca dyplomowa napisana pod opieką Joanny Satoły-Staśkowiak w Akademii Humanistyczno-Ekonomicznej w Łodzi, Łódź.

Włoskowicz W. (2020), Koronawirus jako problem językoznawstwa polonistycznego, „Poradnik Językowy", nr 7.

Атанасова М. (2020), Публикувано във факти.бг: Полиция щурмува хотел в Сандански заради скандално коронапарти, https://fakti.bg/krimi/538657-policia-shturmuva-hotel-v-sandanski-zaradi-skandalno-koronaparti [dostęp: 19.11.2021].

БЛИЦ, https://blitz.bg/ [dostęp: 19.11.2021].

Вацова В. (2020), Новите думи на 2020 г.: ковидиот, локдаун и ковекзит, https://www. 24chasa.bg/ojivlenie/article/9220816 [dostęp: 19.11.2021].

Думата на 2020: коронавирус (2020), https://dnews.bg/dumata-na-2020-koronavirus.html [dostęp: 19.11.2021].

Йорданова Т. (2020), Нови думи в речника ни заради пандемията, https://bntnews.bg/ news/novi-dumi-v-rechnika-ni-zaradi-pandemiyata-1056075news.html [dostęp: 19.11.2021].

Коя е Думата на Безпрецедентната 2020 Г.? (2020), https://boulevardbulgaria.bg/articles/ koya-e-dumata-na-bezpretsedentnata-2020-g [dostęp: 19.11.2021].

Новите думи в българския език (2020), https://nova.bg/news/view/2020/06/28/292238/ $\%$ D0\%BD $\%$ D0\%BE $\%$ D0 $\%$ B2\%D0\%B8\%D1\%82\%D0\%B5-\%D0\%B4\%D1\%83\%D0\%BC\%D0\%B8-\%D0\%B2-\%D0\%B1\%D1\%8A\%D0\%BB\%D0\%B3\%D0\%B0\%D1\%80\%D

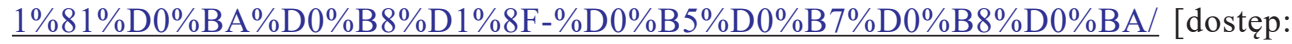
19.11.2021].

\section{Korpusy językowe i wybrane wyszukiwarki}

Ústav Českého národního korpusu Univerzita Karlova Filozofická fakulta, https://ucnk.ff.cuni. cz/cs [dostęp: 18.11.2021].

Słowa na czasie, http://www.slowanaczasie.uw.edu.pl/ [dostęp: 18.11.2021].

Bulgarian National Corpus, http://search.dcl.bas.bg/ [dostęp: 18.11.2021]. 
Český národní korpus, https://korpus.cz/ [dostęp: 18.11.2021].

Frazeo, http://frazeo.pl/ [dostęp: 18.11.2021].

Słownik slangu Miejski.pl, https://www.miejski.pl/ [dostęp: 18.11.2021].

Narodowy Korpus Języka Polskiego, http://nkjp.pl/ [dostęp: 18.11.2021].

\section{Abstract \\ The influence of the pandemic on Polish, Czech and Bulgarian lexicography in 2020 and early 2021}

I discuss the linguistic consequences of the current pandemic, such as the emergence of new words and/or an increase in the frequency of use of some pre-existing words, and issues linked to communication. The paper refers to the Polish, Bulgarian and Czech languages. A frequentative approach is applied. Although the outlined linguistic processes are global in nature, several key aspects differentiate the three chosen languages in terms of frequency (including the occurrence of words and functions of speech).

The linguistic data was gathered using online resources, including: The National Corpus of Polish, the Czech National Corpus, the Bulgarian National Corpus, the Polish-Bulgarian-Russian parallel Corpus (co-authored by the author of this paper), popular word browsers (frazeo.pl, slowanaczasie) and digital dictionaries (miejski.pl), journalism and information programs, and some of the most recent academic literature.

Keywords: pandemic, lexicology, word of the year, neologism, conspiracy theory, frequency of use, the year 2020, Polish language, Bulgarian language, Czech language 